
ЯК ВАЖЛИВИЙ ЧИННИК ФОРМУВАННЯ ПРОФЕСІЙНОЇ КОМПЕТЕНТНОСТІ

Education. Retrieved from http://iite.unesco.org/pics/ publications/ru/files/3214694.pdf [in Russian].

7. Kharkivska, A. A. (2014). Analiz shliakhiv udoskonalennia zmistu profesiinoi pidhotovky maibutnoho vchytelia informatyky [An analysis of ways to improve the content of the training of the future teacher of informatics]. Actual problems of public administration, pedagogy and psychology. Vol. 1, pp.172-174. Retrieved from http://nbuv.gov.ua/UJRN/ apdyptp $2014 \quad 163$. [in Ukrainian].

8. Shovkun, V.V. (2016). Formuvannia profesiinoi kompetentnosti maibutnikh uchyteliv informatyky u kvaziprofesiinii diialnosti [Formation of professional competence of future teachers of informatics in quasiprofessional activity]. Candidate's thesis. Kherson, 244 p. [in Ukrainian].

Стаття надійшла до редакції 06.04.2018

УДК 378.147:614.84-057.86

DOI:

Ігор Ножко, науковий співробітник науково-дослідної лабораторії інноваиій у сфері ичивільної безпеки Черкаський інститут пожежної безпеки імені Героїв Чорнобиля Національного університету циивільного захисту України

\title{
АКТИВІЗАЦІЯ НАВЧАЛЬНОЇ ДІЯЛЬНОСТІ МАЙБУТНІХ ФАХІВЦІВ ПОЖЕЖНОЇ БЕЗПЕКИ ЯК ВАЖЛИВИЙ ЧИННИК ФОРМУВАННЯ ПРОФЕСІЙНОЇ КОМПЕТЕНТНОСТІ
}

Автором здійснено спробу з'ясувати особливості активізації навчальної діяльності майбутніх фахівиів пожежної безпеки в умовах закладу вищої освіти. Доведено, щьо пізнавальна активність передбачає діяльнісний стан особистості, який характеризується прагненням до навчання $і$ прояву вольових зусиль у процесі оволодіння знаннями.

Виокремлено такі основні чинники активізації навчальної діяльності як мотивація та самостійна робота курсантів.

Аргументовано, щзо в умовах реалізаиії нової парадигми вищої освіти актуальною проблемою $\epsilon$ вирішення сучасних проблем організації навчального процесу магістрів як в умовах аудиторної, так $i$ позааудиторної роботи.

Ключові слова: мотив; мотивація; самостійна робота; аудиторна та позааудиторна робота; фахівець пожежної безпеки; професійна компетентність.

Лim. 8.

Ihor Nozhko, Researcher of the Research Laboratory of Innovation in the field of Civil Security Cherkasy Institute of Fire Safety named after Chernobyl Heroes of National University of Civil Defense of Ukraine

\section{INTENSIFICATION OFTRAINING ACTIVITIES OF FUTURE FIRE SAFETY SPECIALISTS AS AN IMPORTANT FACTOR OFFORMING THE PROFESSIONAL COMPETENCE}

The author made an attempt to find out the main factors of intensification of the training activity of future fire safety specialists in the higher educational establishments.

The purpose of the article is to analyze the specific features of intensification of training activities of future fire safety specialists in the higher educational establishments as an important factor in the formation of professional competence.

The following main factors of intensification of educational activity are identified as motivation and self-study of cadets.

It is noted that motivation as an incentive of the organism's activity and its purposefulness promotes self-actualization, self-realization of the personality, causes the need of masters in obtaining the professionally significant knowledge, stimulates the emergence of the desire for professional success, and consequently the formation of professional competence.

The article focuses on the fact that the entire system of the cadets'self-study should be directed to the formation of high professionalism of future fire safety specialists, their readiness to apply the acquired knowledge, skills and abilities. The role of the teacher in the organizing of cadets'self-study is described; an attention is focused on the fact that the teacher should stimulate learning activity, direct it to independent search for additional information.

It is substantiated that skillful organization of self-educational practical activities of future fire safety specialists requires a clear alignment of the goals of the educational process.

It is proved that an actual problem in the conditions of realization of new paradigm of higher education is the solution of modern problems of organization of masters' educational process. 


\section{АКТИВІЗАЦІЯ НАВЧАЛЬНОӤ ДІЯЛЬНОСТІ МАЙБУТНІХ ФАХІВЦІВ ПОЖЕЖНОӤ БЕЗПЕКИ ЯК ВАЖЛИВИЙ ЧИННИК ФОРМУВАННЯ ПРОФЕСІЙНОЇ КОМПЕТЕНТНОСТІ}

The aspects of further scientific research are seen in the development of specific methods and techniques for stimulating cognitive activities of future fire safety specialists.

Keywords: motive; motivation; self-study; class work and extracurricular work; fire safety specialists; professional competence.

П остановка проблеми. Професійна компетентність майбутніх фахівців пожежної безпеки постає визначальним чинником, від якого залежить успіх реалізації соціальних, пізнавальних та інших значущих функцій $[4,89]$. Сучасний стан вищої освіти вимагає формування особистості майбутнього фахівця пожежної безпеки, яка б володіла пізнавальною активністю.

Пізнавальна активність передбачає діяльнісний стан особистості, який характеризується прагненням до навчання і прояву вольових зусиль у процесі оволодіння знаннями $[7,14]$. У зв'язку з цим здійснено спробу з'ясувати основні фактори мотивації навчальної діяльності майбутніх фахівців пожежної безпеки в умовах закладу вищої освіти на магістерському рівні.

Мета статті - проаналізувати особливості активізації навчальної діяльності майбутніх фахівців пожежної безпеки в умовах закладу вищої освіти як важливого чинника формування професійної компетентності.

Аналіз останніх досліджень і публікацій. Концептуальні положення та науково-методичні засади підготовки фахівців цивільного захисту висвітлюють О. Бикова, М. Варій, Н. Вовчаста, В. Доманський, О. Іващенко, I. Коваль, А. Майборода, I. Мельник, В. Ротарь, Т. Ткаченко та ін.

Так, Т. Ткаченко розкриває організаційнопедагогічні умови формування професійної компетентності фахівців безпеки життєдіяльності засобами інформаційно-комунікаційних технологій.

Професійна компетентність майбугніх фахівців пожежної безпеки $є$ предметом наукових розвідок А. Майбороди, І. Мельника, В. Ротаря та ін.

Ці вагомі доробки сучасних науковців стали підгрунтям для подальших наукових розвідок, зокрема в галузі магістерської підготовки майбутніх фахівців пожежної безпеки, а передовсім - для розробки навчальнометодичного забезпечення.

Виклад основного матеріалу. Суттєвим фактором активізації навчальної діяльності магістрів (у нашому випадку - майбутніх фахівців пожежної безпеки) є розвиток мотиваційних засад. Мотив можна та потрібно активізувати шляхом створення відповідної навчально-виховної ситуації, причому результатам курсант повинен завдячувати собі, а не випадковим обставинам, оцінивши свою працю, здібності, наполегливість.
Мотивація як "спонука активності організму і його цілеспрямованості” [6, 327] сприяе самоактуалізації, самореалізації особистості, викликає потребу магістрів уздобугті професійно значимих знань, стимулює виникнення прагнення професійного успіху, а отже - формуванню професійної компетентності.

У розрізі нашого дослідження особливої актуальності набуває наукова позиція О. Іващенко. Досліджуючи структуру професійної готовності майбутніх фахівців ДСНС України до діяльності в екстремальних умовах, науковець доходить висновку, що “мотиваційний компонент готовності передбачає особистісно-професійну потребу, бажання та прагнення успішно оволодіти необхідними знаннями та навичками та виконати службову задачу на основі наявних знань, умінь, досвіду” $[1,106]$. Погоджуємося, що цей компонент несе у собі: потребу реалізуватися в обраній професії; прагнення самостійно ставити і досягати мети професійної діяльності; комплекс уявлень про себе як про професіонала, професійну спрямованість особистості, ступінь старанності в діяльності. В умовах закладу вищої освіти необхідним $€$ орієнтування курсантів на професійний та особистісний розвиток і саморозвиток в освітньому процесі.

Розглядаючи особливості формування мотиваційної сфери курсантів, доцільно акцентувати увагу на таких характеристиках, як стійкість, динамічність, індивідуальний характер тощо. Важливим при цьому є моделювання тих ситуацій, у яких доведеться працювати майбутнім фахівцям.

Визначальним фактором активізації пізнавальної діяльності майбутніх фахівців пожежної безпеки $є$ підвищення уваги викладацького колективу до самостійної роботи курсантів як в умовах аудиторної, так і позааудиторної роботи. У процесі самостійної роботи курсант "засвоює необхідні знання, оволодіває вміннями і навичками, навчається планомірно, систематично працювати, мислити, формує свій стиль розумової діяльності... й організовує свою діяльність відповідно до поставлених завдань" [5, 62].

Основні теоретичні відомості курсанти отримують під час вивчення дисциплін професійної підготовки (обов'язкової та вибіркової): "Управління пожежогасінням", "Пожежна профілактика в населених пунктах", 

ЯК ВАЖЛИВИЙ ЧИННИК ФОРМУВАННЯ ПРОФЕСІЙНОӤ КОМПЕТЕНТНОСТІ

“Організація експлуатації протипожежної техніки”, “Пожежна безпека об'єктів підвищеної небезпеки”, “Державне регулювання діяльності у сфері цивільного захисту”, “Автоматичні системи забезпечення протипожежного захисту”. Серед дисциплін вибіркової підготовки є такі: “Організація аварійно-рятувальних робіт”, “Управління пожежогасінням”, “Теоретичні основи пожежовибухонебезпеки”, “Організація експлуатації засобів захисту органів дихання та тіла", "Системи забезпечення пожежної безпеки об’єктів”, “Інженерна та аварійно-рятувальна техніка".

Уся система самостійної роботи курсантів повинна спрямовуватися на формування високого професіоналізму майбутніх фахівців пожежної безпеки, їхньої готовності до застосування набутих знань, умінь та навичок. Визначальним елементом цієї системи є зорієнтованість на формування у курсантів навичок самостійної реалізації основних функцій діяльності фахівця пожежної безпеки. Основними 3 них $є$ : координація пожежно-профілактичної роботи, розробка комплексних заходів щодо забезпечення пожежної безпеки; внесення у колективні договори пропозицій, спрямованих на підвищення рівня протипожежного захисту населення; проведення вступних протипожежних інструктажів, ведення обліку цих інструктажів; навчання та перевірка знань 3 питань пожежної безпеки; проведення паспортизації структурних підрозділів, дільниць, робочих місць щодо відповідності їх вимогам пожежної безпеки; підготовка звітних матеріалів та відповідної інформації щодо пожеж тощо.

Головним показником ефективності самостійної роботи курсантів $є$ сформованість практичних умінь. До прикладу: удосконалення та координація пожежно-профілактичної роботи, організація розробки комплексних заходів щодо забезпечення пожежної безпеки, погодження їх в органах державного пожежного нагляду і контроль за їх виконанням; здійснення контролю за виконанням законодавчих та інших нормативних актів (стандартів, норм, правил тощо) 3 питань пожежної безпеки, а також наказів, розпоряджень 3 цих питань, вимог приписів і постанов органів державного пожежного нагляду; погодження проектів документів з питань пожежної безпеки, які розробляються структурними підрозділами певної установи; організація проведення нарад, семінарів щодо вдосконалення роботи із забезпечення пожежної безпеки, діяльності пожежно-технічної комісії, добровільної пожежної дружини; організація розслідування причин та обставин виникнення пожеж; організація проведення інструктажів, навчання та перевірки знань із питань пожежної безпеки; надання методичної допомоги структурним підрозділам 3 цих питань тощо.

Це означає, що система як аудиторної, так і позааудиторної роботи повинна забезпечувати таке освітнє середовище, в якому курсант мав би можливість визначити шляхи професійного розвитку та самовдосконалення. Позитивна динаміка активізації навчальної діяльності у процесі організації самостійної роботи майбутніх фахівців пожежної безпеки можлива за умови урізноманітнення форм і методів аудиторної та позааудиторної самостійної роботи.

Так, серед методів навчання майбутніх рятувальників (за І. Коваль) особлива увага має приділятися інтерактивним: пізнавальним (мінілекції, дискусії, мозковий штурм, контролю), тренувальним (ділові ігри, творча праця, фасилітація, модерація), контролювальним (тестування, оцінювання, мотивувальний контроль, самодіагностика $[2,11]$.

Погоджуємося, що застосування ділових ігор дає змогу максимально наблизити навчальний процес до практичної діяльності, приймати рішення в умовах конфліктних ситуацій, відстоювати свої пропозиції, розвивати в учасників гри колективізм та відчуття команди, отримати результати за обмежений час тощо $[3,48]$.

Вихованню здатності до самостійної роботи сприятиме розробка і впровадження електронних навчально-методичних комплексів, які включають електронні навчальні курси, системи комп'ютерного тестування, відео демонстрації тощо. Окреслені форми роботи дають можливість: подавати навчальну інформацію у різних формах; ініціювати процеси засвоєння знань, набугтя вмінь і навичок навчальної або практичної діяльності; ефективно здійснювати повторення та контроль за результатами навчання; активізувати пізнавальну діяльність; формувати й розвивати певні види діяльності [8, 115].

Роль викладача при цьому полягає не так у контролі за самостійною роботою курсанта, як у стимулюванні навчальної діяльності, спрямуванні iï на самостійний пошук додаткової інформації. Уміла організація самостійної практичної діяльності майбутніх фахівців пожежної безпеки потребує чіткого узгодження цілей навчальновиховного процесу.

На основі здійснення наукових розвідок 3 окресленої проблеми доходимо висновку, що освітнє середовище закладу вищої освіти є вагомим чинником формування професійної 
компетентності майбутнього фахівця (у нашому випадку - фахівця пожежної безпеки). Активізація навчальної діяльності майбутніх фахівців пожежної безпеки значною мірою обумовлюється підвищенням уваги професорсько-викладацького колективу до розвитку мотиваційної сфери курсанта та урізноманітненням форм і методів як аудиторної, так і позааудиторної самостійної роботи курсантів. Важливим при цьому залишається самостійна робота курсантів на всіх етапах навчання.

Перспективи подальших наукових розвідок вбачаємо у розробці специфічних методів і прийомів активізації пізнавальної діяльності майбутніх фахівців пожежної безпеки.

\section{ЛІТЕРАТУРА}

1. Іващенко О. А. Структура професійної готовності до діяльності в ектремальних умовах / О. А. Іващенко // Професійна освіта: методологія, теорія та технології. - 2015. - № 2. - С. 100 111.

2. Коваль I. С. Формування професійної готовності майбутніх рятувальників до діяльності в екстремальних умовах: автореф. ... к. пед. наук: 13.00.04 - теорія і методика професійної освіти / І.С. Коваль. - Львів, 2017. - 23 с.

3. Маладика Л. В. Ділові ігри в процесі вивчення професійно орієнтованих дисциплін майбугнімифахівцямипожежноїбезпеки/Л.В.Маладика // Професійна освіта. Наукові записки. Серія: педагогіка. - 2014. - № 4. - С. 42 - 48.

4. Мельник I. В. Професійна компетентність як компонент професійного стилю спілкування майбугніх фахівців пожежної безпеки / І. В. Мельник // Вісник Черкаського університету. - 2016. - №4. - C. $88-92$.

5. Мороз О.Г. Педагогіка і психологія вищої школи: навч. посіб. / О.Г. Мороз, О.С.Падалка, В.І. Юрченко; За заг. ред. О.Г. Мороза. - К. : НПУ. $-2003 .-267$ c.

6. Педагогічний словник / За ред. М.Д. Ярмаченка. - К. : Педагогічна думка. 2001. - 536 с.

7. Словарь, справочник по педагогике / Под. ред. П. И. Пидкасистого. - Москва: ТЦ Сфера, 2004. -439 c.

8. Ткаченко Т. Організаційно-педагогічні умови формування професійної компетентності фахівців безпеки життєдіяльності засобами інформаційнокомунікаційних технологій / Т. Ткаченко // Наукові записки Тернопільського національного педагогічного університету імені Володимира Гнатюка. Серія: Педагогіка. - 2009. - № 3. C. $114-118$.

\section{REFERENCES}

1. Ivashchenko, O.A. (2015). Struktura profesiinoi gotovnosti do diyalnosti v ekstremalnyh umovah [Structure of professional readiness for activities in extreme conditions]. Professional education: methodology, theory and technology no.2, pp.100 111. [in Ukrainian].

2. Koval, I.S. (2017). Formuvannya profesiinoi gotvnosti maybutnih ryatuvalnykiv do diyalnosti $v$ ekstremalnyh umovah [Formation of professional readiness of future rescuers to work in extreme conditions]. Lviv, 23p. [in Ukrainian].

3. Maladyka, L.V. (2014). Dilovi ihry v protsesi vyvchennya profesiino orientovanyh dystsyplin maibutnimy fahivtsyamypozhezhnoi bezpeky [Business games in the process of studying professionally oriented disciplines by future fire safety specialists]. Profesiina osvita. Naukovi zapysky Professional education. Scientific notes. No.4, pp.4248. [in Ukrainian].

4. Melnyk, I.V. (2016). Profesiina kompetentnist yak component profesiinogo stylyu spilkuvannya maibutnih fahivtsiv pozhezhnoi bezpeky [Professional competence as a component of the professional style of communication of future fire safety specialists]. Cherkasy University Bulletin. No.4, pp.88-92. [in Ukrainian].

5. Moroz, O. G., Padalka, O.S. \&Yurchenko, V.I. (2003). Pedagogika i psyhologiia vyshchoi shkoly: navchalnyi posibnyk [Pedagogy and psychology of higher education].Kyiv, 267p. [in Ukrainian].

6. Yarmachenko, M.D. (Ed.). (2001). Pedagogichnyi slovnyk [Pedagogical dictionary]. Kyiv: Pedagogichna dumka. 536 p. [in Ukrainian].

7. Pidkasystyi, P.I., (2004). Slovar, spravochnik po pedagogike [Dictionary, reference book on pedagogy]. Moscov, 439p. [in Russian].

8. Tkachenko, T. (2009). Organizatsiinopedagogichni umovy formuvannya profesiinoi kompetentnosti fahivtsiv bezpeky zhyttyediyalnosti zasobamy informatsiino-komunikatsiinuh tehnologii [Organizational-pedagogical conditions of formation of professional competence of life safety specialists by means of information and communication technologies]. Scientific notes of Ternopil National Pedagogical University named after Volodymyr Hnatyuk. Series: Pedagogy. No.3, pp.114-118. [in Ukrainian].

Стаття надійшла до редакції 26.03.2018

\section{G580}

